\title{
Comparing Peak and Residual Soil Pressures Measured by Pressure Bulbs and Stress-State Transducers
}

\author{
R. L. Raper, F. J. Arriaga
}

\begin{abstract}
Measurement of soil compaction caused by vehicle loading is difficult and often subject to extreme variability. Two types of soil transducers were compared in an experiment conducted in a Norfolk sandy loam soil in the USDA-ARS National Soil Dynamics Laboratory's (NSDL) soil bin facilities. Stress-state transducers (SSTs), electronic transducers developed at the NSDL for measuring six directional pressures and determining the stress state, were used for this experiment. Rubber bulbs connected by a rubber hose to a dial pressure gauge, which measure hydrostatic pressure, were also used in this experiment. Both transducers were buried at depths of 7.5, 15, or $23 \mathrm{~cm}$ and were used to measure soil pressures caused by a 30.5L-32 tire with dynamic loads of 19 or $37 \mathrm{kN}$. The SSTs were buried by inserting them into an excavated hole, while the rubber bulbs were inserted with a special tool designed to leave the soil surface and surrounding soil undisturbed. Peak values of mean normal stress (calculated from measurements of pressure) from the SSTs and hydrostatic pressure measured with the rubber bulbs were found to be affected by both loading and burial depth. Similar magnitudes and variation were observed for each transducer. Residual pressure, defined as the pressure remaining after loading was removed, was found to be affected by both loading and burial depth when measured with the rubber bulbs. Continued development and testing of the rubber bulb transducers could provide a simple method of determining levels of compaction that could damage soils and thus prevent excessive trafficking.
\end{abstract}

Keywords. Dynamic load, Soil compaction, Soil pressures, Soil stress, Transducer.

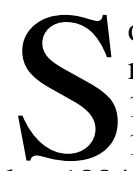

oil compaction reduces crop yields and causes environmental damage (Alblas et al., 1994; Barber, 1994; Box and Langdale, 1984; Gaultney et al., 1982; Reeder and Wood, 1991; Schuler and Kostichka, 1994; Schuler and Lowery, 1984; Schwab et al., 2002; Tupper et al., 1987). Many studies have documented that soil compaction increases runoff and soil erosion (Voorhees et al., 1979) and reduces rooting volume, plant size, infiltration, and water storage (Craul, 1994; Ess et al., 1998; Gayle et al., 1992; Unger and Kaspar, 1994). To understand and potentially reduce the effects of soil compaction, accurate methods of measuring soil compaction must be established.

Measuring soil compaction is especially difficult given soil's natural variability. Two methods have been developed for relatively rapid determination of existing soil compaction in fields. Bulk density has emerged as one of the primary methods that allows researchers to determine if a soil is in a compactable state (Erbach, 1982). Samples of soil of a specific volume are obtained, dried, and then weighed to obtain mass per unit volume. However, this process is extremely

Submitted for review in September 2005 as manuscript number PM 6071; approved for publication by the Power \& Machinery Division of ASABE in December 2006. Presented at the 2005 ASAE Annual Meeting as Paper No. 051159.

The use of trade names or company names does not imply endorsement by USDA-ARS.

The authors are Randy L. Raper, ASABE Member Engineer, Agricultural Engineer and Lead Scientist, and Francisco J. Arriaga, ASABE Member, Soil Scientist, USDA-ARS National Soil Dynamics Laboratory, Auburn, Alabama. Corresponding author: Randy L. Raper, USDA-ARS National Soil Dynamics Laboratory, 411 S. Donahue Dr., Auburn, AL 36832; phone: 334-844-4654; fax: 334-887-8597; e-mail: rlraper@auburn.edu. time-consuming, as many samples must be obtained due to soil's inherent variability.

Cone index is another soil measurement that can be used to determine if a soil is compacted. A cone attached to a rod is inserted into the soil while the force is continuously recorded. The cone index is obtained by dividing the insertion force by the base cross-sectional area of the inserted cone (ASAE Standards, 2004a, 2004b). This measurement is superior to bulk density in some ways because it is much simpler and quicker to obtain. Many measurements of cone index can be obtained over a field in a short period of time, allowing investigators to produce field maps of measured soil compaction.

The previously mentioned measurements of soil compaction are useful tools to determine existing conditions of compaction. However, methods that can be used to measure soil compaction as it occurs are especially useful to determine the detrimental effects of vehicle traffic. Electronic transducers that can measure soil pressures as vehicles pass over them have been used for many years with varied success.

The development of the stress-state transducer (SST) was a milestone that allowed accurate measurements of soil pressures and calculation of principal soil stresses (Nichols et al., 1987). The SST has been used for many experiments and was instrumental in showing that reduced tractor tire inflation pressure also contributed to reduced soil stresses (Bailey et al., 1996). However, the SST requires six electronic pressure cells that also require electronic instrumentation. Many soil compaction problems could potentially be solved with simpler measurement techniques.

One of the simpler technologies that have been developed for the measurement of soil compaction requires a rubber membrane be placed in the soil under agricultural vehicles. 
Bolling (1985) proposed inserting a balloon at an angle to the soil surface and monitoring a water column for increased soil pressures. Turner et al. (2001) and Turner and Raper (2001) described a similar technique that required a rubber bulb to be inserted and attached via a long, flexible, rubber hose to a pressure gauge. These technologies require no electronic instrumentation and can quickly result in useful measurements.

Another advantage of the flexible membrane measurement technologies is that they also allow measurements of residual pressure, or the pressure remaining after the load has been removed. Residual pressures may be a better indicator than peak pressure of resulting soil compaction due to soils elastic-plastic behavior, which allows it to rebound after loading. The objectives of this experiment were therefore:

- To compare the sensitivity and variability of the SST and a rubber pressure bulb for measuring peak soil pressures.

- To compare peak and residual soil pressures as measures of soil compaction.

\section{Methods ANd Materials}

An experiment was conducted in the soil bins at the USDA-ARS National Soil Dynamics Laboratory to determine the effects of dynamic load on soil pressures as measured by two different transducers and on soil compaction as measured by bulk density and cone index. This experiment was conducted in an indoor soil bin containing Norfolk sandy loam soil (fine loamy, kaolinitic, thermic Kandiudults). Norfolk sandy loam soil is a Coastal Plain soil commonly found in the southeastern U.S. and along the Atlantic Coast.

The soil condition used for the experiment was created by using a rotary tiller. The soil was tilled down to a depth of $60 \mathrm{~cm}$ and then left in a relatively loose state. The surface was then bladed and rolled smooth to create a uniform surface.

The tractor tire used in the experiment was a Firestone 30.5L-32 R-1 bias ply agricultural tractor tire that had the lugs filled with rubber (fig. 1). The Traction Research Vehicle (TRV) was used to conduct the experiment. This machine is capable of operating and controlling a single tire for use in the

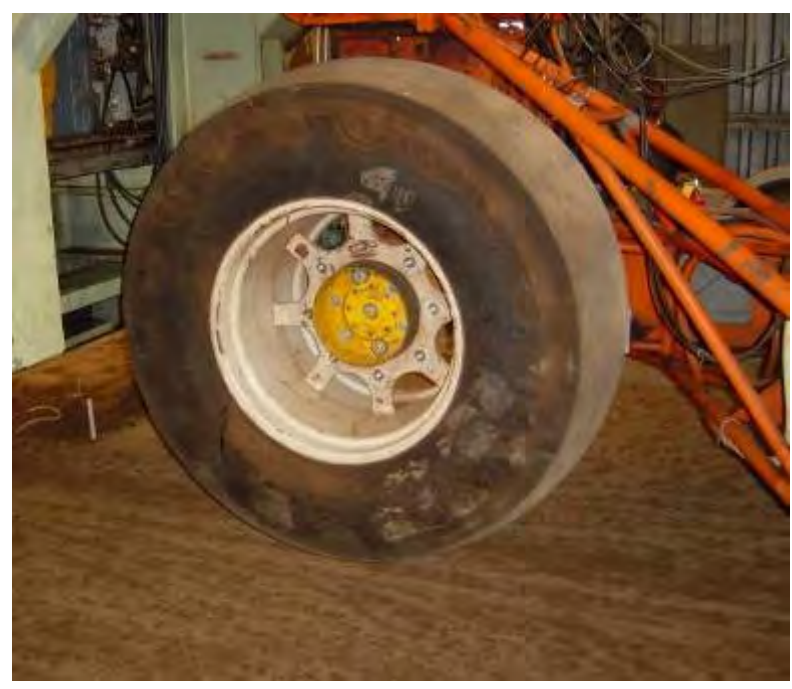

Figure 1. Tire mounted on TRV.

soil bins, as described by Burt et al. (1980) and Lyne et al. (1983). The tire was operated in the following manner: two load levels of $19 \mathrm{kN}$ and $37 \mathrm{kN}$, inflation pressure of $110 \mathrm{kPa}$, $0 \%$ travel reduction, speed of $0.08 \mathrm{~m} / \mathrm{s}$, with four replications.

The SSTs (fig. 2) were buried in the center of the path of the tire. These transducers measured the soil pressures in six directions and provided values that allowed the calculations of principal stresses. Instrumentation was used that enabled all six channels of pressure to be measured over the entire period that the tire was moving across the transducers. The burial procedure for these transducers consisted of placing a piece of plywood on the soil surface adjacent to where the transducer was to be located. A large hole was then excavated with posthole diggers, and the loose soil was placed on the plywood. After the SST transducer was placed in the bottom of the hole at the appropriate depth, the loosened soil was carefully placed back in the hole. Any remaining soil was uniformly distributed across the soil surface.

The pressure bulbs were similar to those described and used by Turner and Raper (2001), which were hydraulically

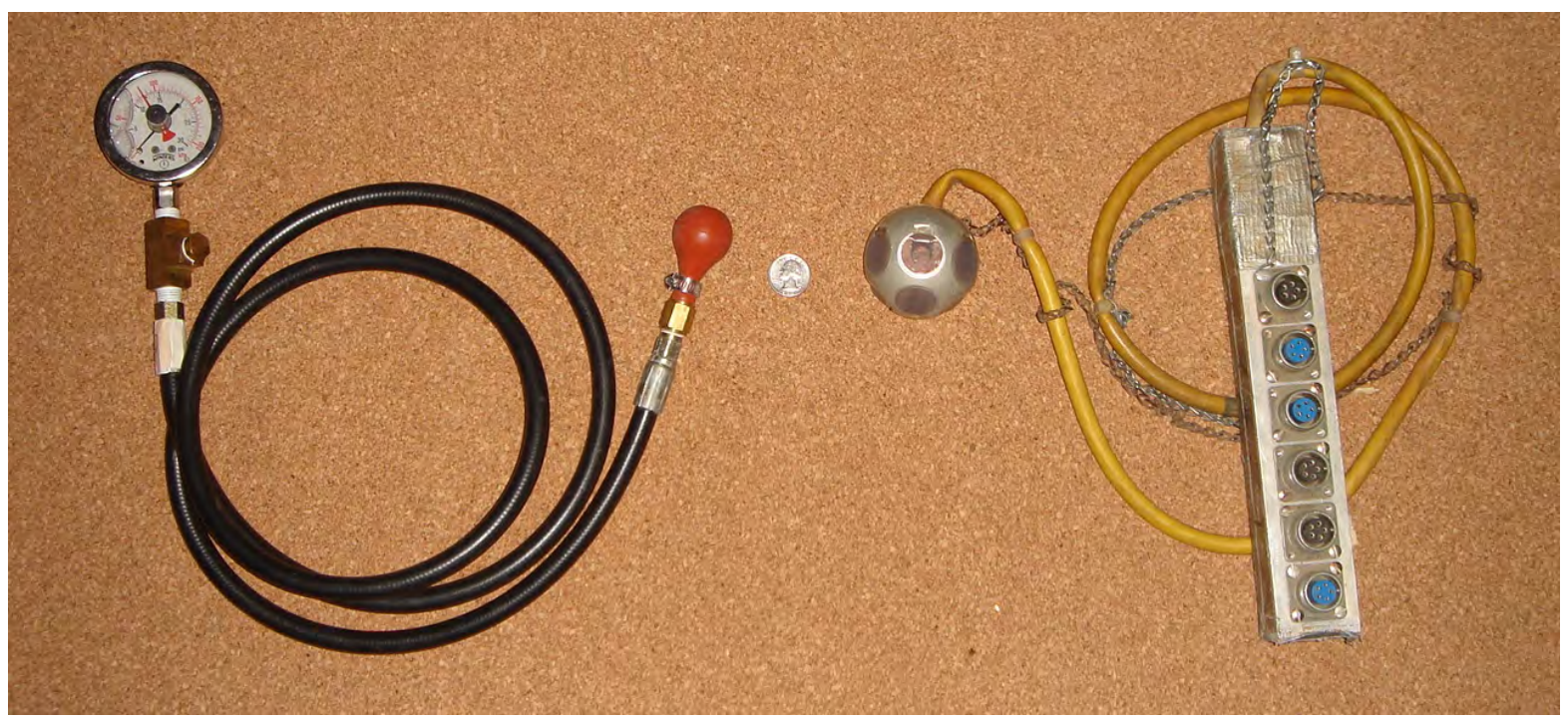

Figure 2. Rubber bulb with pressure gauge (left) and SST (right). 
filled rubber lines and bulbs attached to a dial pressure gauge (fig. 2). No instrumentation was used to monitor the pressures measured by the bulbs. Each dial gauge had a peak measurement needle that stayed at the maximum value that was measured by the bulb. The burial procedure for the bulbs consisted of using a screw-type auger to remove a column of soil angling downward to the desired location of the bulb transducer. An angle of approximately $45^{\circ}$ perpendicular to the direction of tire travel was used to allow the dial pressure gauge to be located outside of the tire track.

The SSTs were buried in the center of the tire track at three depths: $7.5,15$, and $23 \mathrm{~cm}$. Values measured with the SSTs were compared against the measurements with the bulbs at similar depths.

Mean normal stresses calculated from pressures measured by the SST were used to compare to pressures measured by the bulb. The mean normal stress was calculated as the average of the vertical and perpendicular side pressures measured by the SST. This value was thought to be similar to the hydrostatic pressure measured by the pressure bulb.

Ten measurements of cone index were obtained per replication prior to the test to determine the original soil condition. The Rimik manual penetrometer (Toowoomba, Australia) was used to acquire the cone index data. At the conclusion of the experiment, three replications per plot were obtained to determine the resulting soil condition from the load application.

Prior to the experiment, one measurement of bulk density was obtained per replication at each of the three depths at which transducers were placed $(7.5,15$, and $23 \mathrm{~cm})$. At the conclusion of the experiment, one measurement of bulk density was obtained per plot at each of the three different final burial depths of the transducers $(5.1,8.8$, and $14.2 \mathrm{~cm})$.

The randomized complete block experiment was analyzed with an appropriate ANOVA model using SAS (Cary, N.C.). Treatment effects were separated using single degree of freedom contrasts. A predetermined significance level of $\mathrm{P} \leq 0.1$ was chosen to separate treatment effects.

\section{Results AND Discussion}

\section{RUT DEPTH}

The soil surface was deformed significantly by the applied dynamic loads $(\mathrm{P} \leq 0.01)$. A dynamic load of $19 \mathrm{kN}$ deformed the surface by $11.3 \mathrm{~cm}$, while a dynamic load of $37 \mathrm{kN}$ deformed the surface by $14.9 \mathrm{~cm}$. No significant differences in surface deformation were found as a result of different burial depths.

\section{Bulk Density}

The initial bulk density measured before any tests were $1.21,1.25$, and $1.21 \mathrm{Mg} / \mathrm{m}^{3}$ at the $7.5,15$, and $23 \mathrm{~cm}$ depths, respectively (fig. 3). At the same depths, gravimetric soil moisture was found to be $6.8 \%, 7.7 \%$, and $7.5 \%$, respectively. Both loads increased bulk density dramatically from its original state at all depths. The final values of bulk density were found to be affected by dynamic load $(\mathrm{P} \leq 0.01)$ but not by depth of burial, with the $19 \mathrm{kN}$ dynamic load resulting in a final average bulk density of $1.55 \mathrm{Mg} / \mathrm{m}^{3}$ and $37 \mathrm{kN}$ resulting in $1.67 \mathrm{Mg} / \mathrm{m}^{3}$.

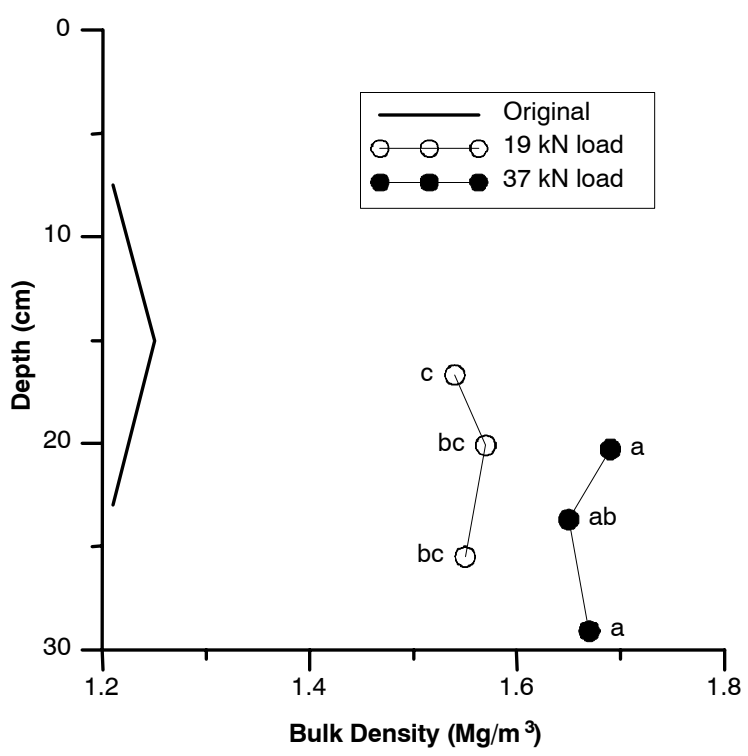

Figure 3. Bulk density plotted at original burial depths for original soil condition and at final depths after applied loading. Letters indicate statistical significance between loads and depths $\left(\mathrm{LSD}_{0.1}\right)$.

\section{CONE INDEX}

Cone index was significantly increased by dynamic load ( $\mathrm{P} \leq 0.01$; fig. 4) as compared with the initial cone index values taken before the experiment was started. The largest load $(37 \mathrm{kN})$ increased the cone index the greatest amount, with the smaller load $(19 \mathrm{kN})$ having a reduced impact. The dynamic load increased cone index over the entire depth in which measurements were acquired, but its impact was greatest near the surface.

\section{SST MEASUREMENTS \\ Depth to SST}

The original soil placed above the SST after burial was compressed significantly by the loading process; however, the specific amount of the load (19 or $37 \mathrm{kN})$ did not affect the burial depth $(\mathrm{P} \leq 0.52)$. The SSTs originally placed at

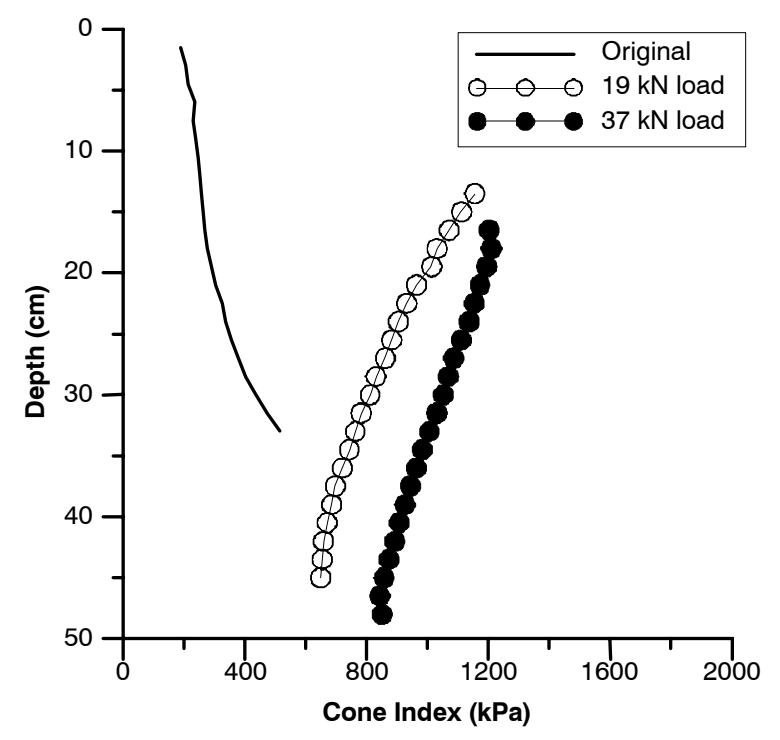

Figure 4. Cone index plotted for original soil condition and after applied loading. 


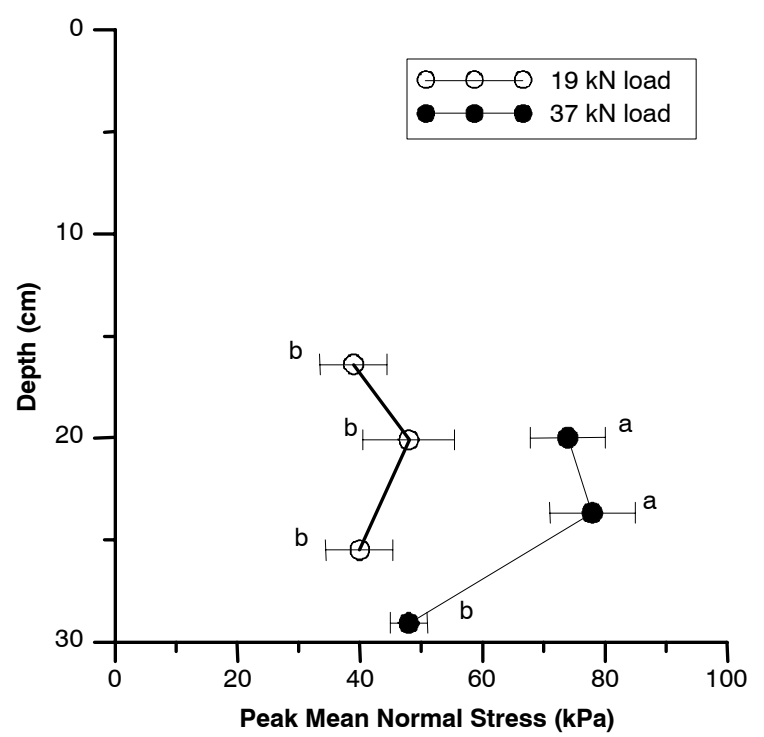

Figure 5. Peak mean normal stress by depth as measured with the SST after applied loading. Letters indicate statistical significance between loads and depths $\left(\mathrm{LSD}_{0.1}\right)$. Error bars indicate standard deviations of the measurements.

depths of $7.5,15$, and $23 \mathrm{~cm}$ were found at depths of 5.1, 8.8, and $14.2 \mathrm{~cm}$, respectively.

\section{Peak Mean Normal Stress}

Peak mean normal stress was statistically affected $(\mathrm{P} \leq$ 0.01 ; fig. 5) by loading, with $37 \mathrm{kN}$ causing peak mean normal stress of $66.8 \mathrm{kPa}$ and $19 \mathrm{kN}$ resulting in $42.5 \mathrm{kPa}$ when averaged across all depths. Maximum values of peak normal stress were measured closer to the soil surface. At the deepest burial depth, no difference was found between the two different loads applied at the soil surface. At all other depths, significant differences in stress were found.

The variation of the SST peak mean normal stress measurements was quite large, particularly at the shallow and medium burial depths, as indicated by the size of the error bars (fig. 5). However, the differences between the means were large enough to allow statistical significance to be found between loads at similar original burial depths. At the deepest burial depth, reduced variation in the peak mean normal stress data was not sufficient to allow differences to be found between the two applied loads.

\section{Residual Mean Normal Stress}

The physical meaning of the residual mean normal stress as measured with the SST was suspect due to the nature of the electronic transducers. One of the reasons that the residual stress measurements were not useful was that the magnitudes of these measurements were small (table 1). Most values had standard deviations greater than $50 \%$ of the magnitude of the measurement, which indicated that random noise may be a significant part of the value. Another reason that the residual stress measurements may not be useful is that the directional pressure transducers cannot measure below $0 \mathrm{kN}$. After the loading has been applied and removed, soil on the rigid, multi-face SST may pull away from the directional pressure cells and not be in physical contact. If contact were still possible, a negative pressure would be sensed by the directional pressure cells that had soil pulling on them. Due to the lack of physical contact between soil and some of the directional pressure cells, the actual pressure measured by those directional pressure cells would be random noise near zero. This is clearly seen by the measurements for the residual side stress, which vary about $0 \mathrm{kN}$. Averaging those orthogonal pressure cell measurements would significantly affect the mean normal stress and render it useless.

\section{Bulb Measurements \\ Final Depth}

The original depths of bulb burial were reduced from 7.5, 15 , and $23 \mathrm{~cm}$ to $5.1,9.9$, and $13.0 \mathrm{~cm}$, respectively. Increased compression of the soil occurred with depth, as the final shallow burial depth $(5.1 \mathrm{~cm})$ was $68 \%$ of the original burial depth $(7.5 \mathrm{~cm})$, the final medium burial depth $(9.9 \mathrm{~cm})$ was $66 \%$ of the original burial depth $(15 \mathrm{~cm})$, and the final deep burial depth $(13.0 \mathrm{~cm})$ was $58 \%$ of the original burial depth $(23 \mathrm{~cm})$.

\section{Peak Pressure}

Peak pressures as measured with the bulb were found to be significantly affected by load ( $\mathrm{P} \leq 0.01$; fig. 6), with $37 \mathrm{kN}$ causing peak pressure of $51.1 \mathrm{kPa}$ and $19 \mathrm{kN}$ causing peak pressure of $28 \mathrm{kPa}$. Almost constant values of peak pressure were noted at different depths, with statistical significance being found between the loads at each depth.

The variation of the bulb peak pressure values was mostly small, as indicated by the standard deviations of the measurements (fig. 6), particularly when the lower load of $19 \mathrm{kN}$ was used. When the loading increased to $37 \mathrm{kN}$, larger deviations in the data occurred, particularly near the soil surface. Overall, however, the variation found with the bulb was substantially reduced from the variation found with the SST.

\section{Residual Pressure}

Residual pressures measured with the bulb showed similar trends to those found with peak pressures (fig. 7). The greater loading of $37 \mathrm{kN}$ caused increased residual pressures of $38.6 \mathrm{kPa}$, as compared to the $19 \mathrm{kN}$ loading, which caused residual pressures of $26.7 \mathrm{kPa}$. The two loads caused

Table 1. Residual stress measurements with the SST (standard deviations in parentheses).

\begin{tabular}{|c|c|c|c|c|c|}
\hline $\begin{array}{l}\text { Depth } \\
\text { (cm) }\end{array}$ & $\begin{array}{c}\text { Dynamic } \\
\text { Load } \\
(\mathrm{kN})\end{array}$ & $\begin{array}{l}\text { Residual Mean } \\
\text { Normal Stress } \\
{[(x+y+z) / 3]} \\
(\mathrm{kPa})\end{array}$ & $\begin{array}{c}\text { Residual Horizontal Stress } \\
\text { (parallel to tire track) } \\
{[x]} \\
(\mathrm{kPa})\end{array}$ & $\begin{array}{c}\text { Residual Side Stress } \\
\text { (perpendicular to tire track) } \\
{[y]} \\
(\mathrm{kPa})\end{array}$ & $\begin{array}{c}\text { Residual } \\
\text { Vertical Stress } \\
{[z]} \\
(\mathrm{kPa})\end{array}$ \\
\hline 16.4 & 19 & $4.2(3.2)$ & $5.2(0.9)$ & $-0.8(0.3)$ & $5.5(4.9)$ \\
\hline 20.1 & 19 & $2.4(1.2)$ & $4.0(1.0)$ & $-0.1(2.3)$ & $4.6(4.6)$ \\
\hline 25.5 & 19 & $3.3(1.8)$ & $3.7(2.0)$ & $1.7(3.7)$ & $4.6(1.7)$ \\
\hline 20.0 & 37 & $5.2(2.1)$ & $7.3(1.8)$ & $-0.2(0.6)$ & $8.6(5.3)$ \\
\hline 23.7 & 37 & $3.8(1.3)$ & $5.6(2.1)$ & $-1.2(0.7)$ & $7.0(2.8)$ \\
\hline 29.1 & 37 & $2.6(1.6)$ & $4.2(1.6)$ & $-2.6(0.8)$ & $6.2(4.5)$ \\
\hline
\end{tabular}




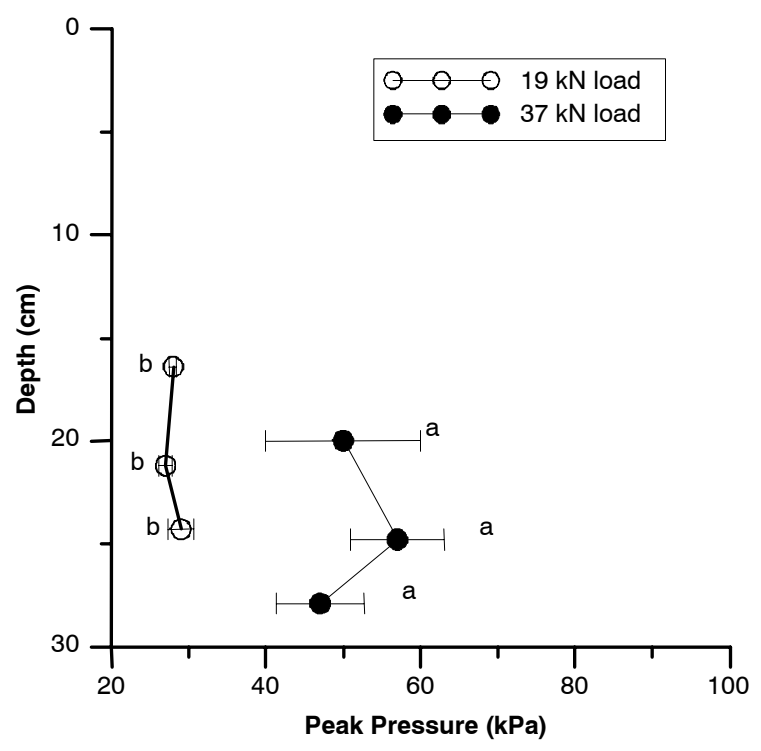

Figure 6. Peak pressure plotted by depth as measured with the pressure bulb after applied loading. Letters indicate statistical significance between loads and depths $\left(\mathrm{LSD}_{\mathbf{0 . 1}}\right)$. Error bars indicate standard deviations of the measurements.

statistically different values of residual pressure to be measured at the two shallower depths but not at the deepest burial depths, where similar values were found.

Small variation in the residual pressure as measured by the pressure bulbs was found at all depths with all loads (fig. 7). The largest standard deviation of residual pressure was found at the shallow burial depth under the $37 \mathrm{kN}$ load, but this increased variation was not large enough to prevent these measurements from being found statistical different from the residual pressure at the $19 \mathrm{kN}$ load at the same depth.

\section{Comparisons of SST and Bulb Measurements}

A slight reduction in magnitude was found with the bulb measured values of 20 to $60 \mathrm{kPa}$ in peak pressure as compared to the SST measured values of 35 to $80 \mathrm{kPa}$ in peak mean normal stress. However, increased precision may have been found, with the bulb able to distinguish between loads at all three depths of burial while the SST was only able to distinguish between loads at the shallower two depths of burial. At the deepest depth of burial $(23 \mathrm{~cm})$, no difference was found between the two loads of 19 and $37 \mathrm{kN}$ for the SST measurements. Particularly at this depth, the SST was unable to distinguish between loads, while peak pressure measured with the bulb was able to sense differences in loading equally well at all depths.

The residual pressures measured with the bulb were also decreased in magnitude from the peak pressures measured with the bulb as well as the peak mean normal stresses calculated from the SST measurements. However, the precision afforded to these measurements was similar to that of the peak mean normal stress measurements obtained with the SST, with no differences in residual pressures being found at the deepest burial depth of $23 \mathrm{~cm}$. Residual stress measurements obtained with the SST were not useful because of the extremely low magnitudes of the measurements and because of the rigid stress transducers inability to sense pressure below $0 \mathrm{kN}$.

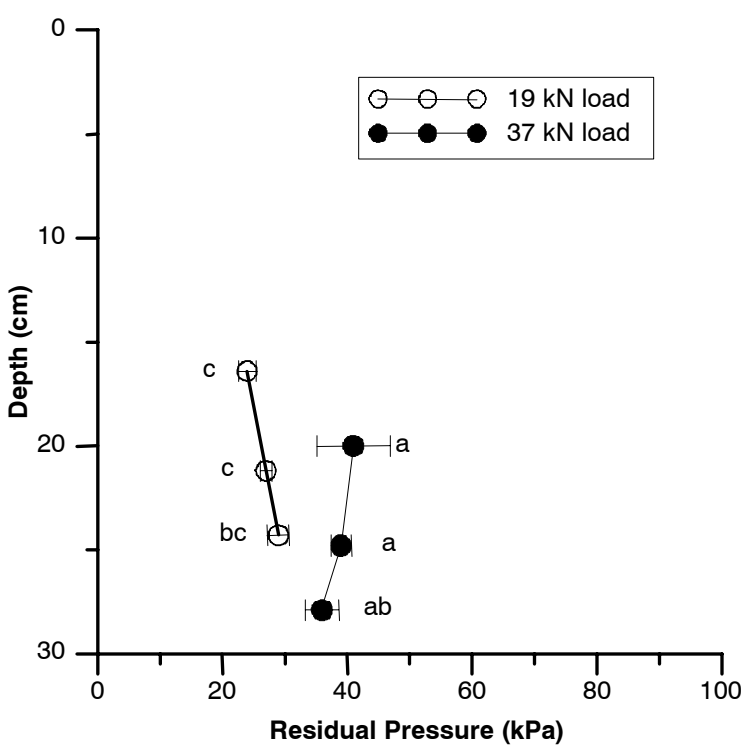

Figure 7. Residual pressure by depth as measured with the pressure bulbs after applied loading. Letters indicate statistical significance between loads and depths $\left(\mathrm{LSD}_{0.1}\right)$. Error bars indicate standard deviations of the measurements.

\section{Conclusions}

The SST and the rubber pressure bulb were both able to distinguish differences in tire loading at shallow and medium original transducer burial depths of 7.5 and $15 \mathrm{~cm}$. However, at the deepest original transducer burial depth of $23 \mathrm{~cm}$, the pressure bulb proved superior because it was able to distinguish differences in applied load, while the SST could not.

Using the rubber bulb to obtain peak pressures proved to be a superior method of discerning between applied loads at the soil surface, as compared to using the residual pressures, which were measured after the loading had been removed. Peak pressures obtained with the rubber bulb were able to discern differences in soil pressures at the deepest original burial depth of $23 \mathrm{~cm}$, while residual pressures could not.

\section{REFERENCES}

Alblas, J., F. Wanink, J. van den Akker, and H. M. G. van der Werf. 1994. Impact of traffic-induced compaction of sandy soils on the yield of silage maize in the Netherlands. Soil Till. Res. 29(2-3): 157-165.

ASAE Standards. 2004a. EP542: Procedures for obtaining and reporting data with the soil cone penetrometer. St. Joseph, Mich.: ASAE.

ASAE Standards. 2004b. S313.3: Soil cone penetrometer. St. Joseph, Mich.: ASAE.

Bailey, A. C., R. L. Raper, E. C. Burt, T. R. Way, and C. E. Johnson. 1996. Soil stresses under a tractor tire at various loads and inflation pressures. J. Terra. 33(1): 1-11.

Barber, R. G. 1994. Persistence of loosened horizons and soybean yield increases in Bolivia. SSSA J. 58(3): 943-950.

Bolling, I. H. 1985. How to predict the soil compaction of agricultural tires. In Proc. Intl. Conference on Soil Dynamics, 936-952. Auburn, Ala.: Auburn University.

Box, J., and G. W. Langdale. 1984. The effects of in-row subsoil tillage and soil water on corn yields in the southeastern coastal plain of the United States. Soil Till. Res. 4(1): 67-78. 
Burt, E. C., C. A. Reaves, A. C. Bailey, and W. D. Pickering. 1980. A machine for testing tractor tires in soil bins. Trans. ASAE 23(3): 546-552.

Craul, P. J. 1994. Soil compaction on heavily used sites. J. Arboriculture 20(2): 69-74.

Erbach, D. C. 1982. State of the art soil density measurement. ASAE Paper No. 821541. St. Joseph, Mich.: ASAE.

Ess, D. R., D. H. Vaughan, and J. V. Perumpral. 1998. Crop residue and root effects on soil compaction. Trans. ASAE 41(5): 1271-1275.

Gaultney, L., G. W. Krutz, G. C. Steinhardt, and J. B. Liljedahl. 1982. Effects of subsoil compaction on corn yields. Trans. ASAE (3): 563-569.

Gayle, G. A., C. W. Raczkowski, and R. Mwazi. 1992. Tillage and wheel-traffic effects on soil properties and root growth. ASAE Paper No. 921556. St. Joseph, Mich.: ASAE.

Lyne, P. W. L., E. C. Burt, and J. D. Jarrell. 1983. Computer control for the NTML single-wheel tester. ASAE Paper No. 831555. St. Joseph, Mich.: ASAE.

Nichols, T. A., A. C. Bailey, C. E. Johnson, and R. D. Grisso. 1987. A stress-state transducer for soil. Trans. ASAE 30(5): 1237-1241.

Reeder, R. C., and R. K. Wood. 1991. Subsoil compaction effects on grain yields and soil properties. ASAE Paper No. 911519. St. Joseph, Mich.: ASAE.
Schuler, R. T., and C. J. Kostichka. 1994. Pre- and post-plant deep tillage in potato production. ASAE Paper No. 941558. St. Joseph, Mich.: ASAE.

Schuler, R. T., and B. Lowery. 1984. Subsoil compaction effect on corn production with two soil types. ASAE Paper No. 841032. St. Joseph, Mich.: ASAE.

Schwab, E. B., D. W. Reeves, C. H. Burmester, and R. L. Raper. 2002. Conservation tillage systems for cotton grown on a silt loam soil in the Tennessee Valley. SSSA J. 66(2): 569-577.

Tupper, G. R., J. G. Hamill, and H. C. Pringle, III. 1987. Cotton response to long-term tillage systems on a silt loam soil in Mississippi. In Proc. Beltwide Cotton Production Research Conferences, 492-495. Memphis, Tenn.: National Cotton Council.

Turner, R. J., and R. L. Raper. 2001. Soil stress residuals as predictors of soil compaction. ASAE Paper No. 011063. St. Joseph, Mich.: ASAE.

Turner, R. J., K. Schmidt, M. Fornier, and K. Lepage. 2001. Development of a simple system for measuring peak soil stresses. ASAE Paper No. 01AETC03. St. Joseph, Mich.: ASAE.

Unger, P. W., and T. C. Kaspar. 1994. Soil compaction and root growth: A review. Agron. J. 86(5): 759-766.

Voorhees, W. B., R. A. Young, and L. Lyles. 1979. Wheel traffic considerations in erosion research. Trans. ASAE 22(4): 786-790. 